\title{
O santo e o encantado: a procissão afro umbandista para São Sebastião em São João de Pirabas
}

\section{Hermes de Sousa Veras}

Universidade Federal do Rio Grande do Sul | Porto Alegre, RS, Brasil

hermesociais@gmail.com

ORCID: https://orcid.org/0000-0002-5740-4028
RESUMO

Todos os dias 19 e 20 de janeiro, em São João de Pirabas, celebra-se uma festividade para Rei Sabá. Rei Sabá, corruptela de Rei Sebastião, é uma entidade que pertence ao panteão dos encantados, seres que não conheceram a experiência da morte. Transformando-se em entes que possuem seu próprio território-a encantaria - esses seres se manifestam a partir de Rei Sabá e de outros agentes. Por meio de uma etnografia em andamento, o artigo apresenta os rituais que antecedem a festividade principal do Rei Sabá, dedicadas a São Sebastião. O objetivo é descrever como as religiões da encantaria marcam e produzem esta cidade no nordeste paraense.

\section{The Saint ANd the Enchanted One: the Afro Umbandist \\ Procession to São Sebastião In São João de Pirabas}

ABSTRACT Every year on January $19^{\text {th }}$ and $20^{\text {th }}$ the municipality of São João de Pirabas celebrates Rei Sabá. Rei Sabá. As a version of of the King Sebastian (Rei Sebastião), he is an entity that belongs to the pantheon of the encantados, beings who did not know the experience of death. These encantados transform themselves into entities that have their own territory - the encantaria - and manifest themselves from Rei Sabá and others agents. Based on an ongoing research, the article presents the rituals that precede the main feast of Rei Sabá, dedicated to St. Sebastian (São Sebastião). The purpose is to describe how the religions of encantaria mark and produce the city itself.
DOI

http://DX.DOI.ORG/

10.11606/1678-9857

RA.2020.189653

1) O protótipo desse texto foi um exercício proposto na disciplina de tópico especial, Religião e Espaço Público, ofertada por Emerson Ciumbelli no âmbito do PPCAS/UFRCS.

Além disso, parte desse trabalho

foi apresentado na $31^{\circ}$ Reunião Brasileira de Antropologia, no grupo de trabalho Performances e marcas da religião na cidade coordenado por Emerson Ciumbelli, Edilson Pereira e Christina Vital da Cunha, a quem agradeço pelas contribuições. Thayanne

Tavares esteve presente em alguns momentos de campo, tendo contribuído para a presente reflexão. Ressalto que pareceristas anônimos deste texto contribuíram para a sua qualificação e melhora.

Para as pessoas de São ]oão

de Pirabas, especialmente o povo de encantaria, deixo meu agradecimento pela recepção e os momentos valorosos passados e que ainda prosseguem.

\section{PALAVRAS-CHAVE}

Afro-brasileiros, umbanda amazônica, encantaria, cidade, Amazônia paraense 


\section{A MULTIPLICIDADE DE REI SABÁ}

Nesse escrito descreverei uma procissão e gira realizadas para São Sebastião no dia 19 de janeiro, fazendo parte do complexo de rituais que antecedem a festividade principal ao encantado Rei Sabá (Rei Sebastião), pois em São ]oão de Pirabas acontecem, há pouco mais de um século, celebrações, festejos, obrigações, cerimônias, enfim, uma variada ritualística dedicada a essa entidade. Pirabas é um município litorâneo, banhado pelo oceano atlântico e o rio de mesmo nome da cidade. A sua localização, na microrregião do salgado paraense, a coloca em uma geografia repleta de praias e ilhas, sendo algumas dessas regiões os locais de encantaria de Rei Sabá.

Rei Sabá é uma entidade múltipla, cultuada e vivenciada de igual maneira. Podemos falar em uma tríade inicial para descrevê-lo: Rei Sebastião, São Sebastião e Oxóssi. Isso se aceitarmos que Rei Sabá e Rei Sebastião são as mesmas personalidades. Caso não, teríamos uma quadriangulação. Esse quadro se torna mais complexo se acompanharmos alguns relatos que dizem que Rei Sebastião é Xapanã (Leacock e Leacock, 1975: 137). Em minha pesquisa, não encontrei essa referência diretamente, mas essa relação é cantada em pontos, nas giras e celebrações: "Ê Xapanã, ele é pai de terreiro". Essa multiplicidade do encantado não deve ser entendida como sinônima entre os seres envolvidos, há, sim, relações. É o que nos conta Pai Sival, Mãe Rita, Pai Zé Pajé, Pai Pingo, Cabocla Mariana (na croa - cabeça de Mãe Rita) e outros interlocutores e interlocutoras.

Em 2019, Pai Sival e Mãe Rita divulgaram que aquele era $0107^{\circ}$ festival afro religioso Rei Sabá. No ano passado, a data era outra, apresentando décadas de diferença. Segundo Pai Sival, em 2018 a prefeitura se equivocou na divulgação dos anos, então eles não quiserem contestar, mas ele afirma que essa datação é de acordo com os antigos, como por exemplo Maria Pajé (já falecida) e Pai Pedrosa (que encontra-se muito doente), lideranças responsáveis pela implementação da festividade da forma que ela acontece atualmente.

Para a concepção deste texto, parto de vivências e conversas com as pessoas que participam da vida da cidade durante trabalho de campo realizado entre janeiro/ fevereiro de 2018. Nessa data, conversei de forma mais aprofundada com duas mulheres, uma jovem mãe de santo de umbanda branca e uma pajé benzedeira', Dona Oneide, de mais de 80 anos de idade. Entretanto, ambas não são ativas na festividade de Rei Sabá, optando por não frequentar o festejo. Em junho de 2018, em razão de uma mesa redonda que participei na Universidade do Estado do Pará (UEPA), em Belém, aproveitei a viagem para ir novamente a Pirabas. Assim, conversei com dois pais de santos de forte atuação local, ambos participam das festividades: Pai Sival, da linha de Pena e Maracá, coordena a Tenda Espírita Preto Velho (que, na ocasião, estava trancada por conta de um filho de santo estar recolhido), e Pai Zé Pajé, do Templo de Umbanda Ogum Beira Mar e Zé Pelintra.

1|A mãe de santo desse centro de umbanda classifica assim o seu terreiro. Devemos ter em mente que a umbanda praticada aqui ainda é a amazônica, isto é, tem referencial na encantaria (umas das lideranças é a encantada Cabocla Mariana, portanto, respeita e reverencia Rei Sabá). Já a benzedeira, Dona Oneide, é guiada por essas entidades da encantaria, além da Arara e outros animais que fazem parte do complexo da encantaria. Assim, as entidades caboclas, por exemplo, não são como as da umbanda sudestina. Na umbanda amazônica há também os caboclos da mata, que são indígenas ou descendentes deles, mas os caboclos possuem outras nacionalidades, assim como participam de outros marcadores étnico-racais: são turcos, portugueses, franceses que habitam a encantaria (Ferretti, 2000; Luca, 2010). Isso não significa que a tecnologia ritual para receber e se relacionar com esses encantados não seja negra, de matriz africana e em constante diálogo com a pajelança. 
Além do mais, desde 11 de janeiro de $2019^{2}$, encontro-me em São João de Pirabas, onde assisti novamente a procissão e a festividade para o Rei Sabá na Praia do Castelo. Assim pude conversar e acompanhar as atividades de Mãe Rita de Oxóssi, que, junto a Pai Sival, organizam grande parte do festejo. Tive a oportunidade de acompanhar a instalação das novas imagens de lemanjá, Toia Jarina, Cabocla Mariana e Zé Raimundo, além de conversar longamente com o Santeiro, personagem que construiu as imagens. Também assisti a um trabalho de Exu no Templo de Ogum Beira Mar e Zé Pelintra, dialogando com Pai Zé Pajé. Por isso, 2019 surgirá de quando em vez para complementar a narrativa, sendo que Pai Sival, Mãe Rita de Oxóssi, do Templo de Umbanda Oxóssi e Mamãe Oxum, Pai Zé Pajé e Dona Oneide se transformaram, ao longo da pesquisa, nos principais interlocutores da etnografia, assim como os encantados e encantadas que os irradiam.

Portanto, em diálogo com minhas interlocutoras e interlocutores, ao acompanharmos os diversos momentos em que Rei Sabá está presente, poderíamos estender essa triangulação infinitamente: ramificando, dividindo, agregando e diferenciando. No Pará é comum que se chame carinhosamente de Sabá a quem tem o nome de Sebastião. É um indício de proximidade. Por esta razão, podemos dizer que Rei Sabá pode ser Rei Sebastião. Cabocla Mariana, a bela turca encantada, na croa de Mãe Rita de Oxóssi me garantiu: Rei Sabá era um passeador das águas do Maranhão e do Pará, acabou por se encantar nessas regiões. Quando em forma de gente, aparece como um homem branco, alto e bonito, podendo surgir, em outros momentos, virado em Cobra Grande, e por isso, Cabocla Mariana Ihe deu a alcunha de Rabudo.

Rei Sabá tem morada na ilha da Fortaleza, na praia do Castelo, território que fica nas imediações aquáticas da cidade. A entidade tem como umas de suas existências materiais uma pedra escura. A pedra tinha, ou tem, a depender do ângulo e da percepção, o formato de uma pessoa sentada. Com as reformas da prefeitura, na gestão de Bosco Moisés (2000-2008), a pedra, uma manifestação natural esculpida pela natureza, como algumas pessoas de Pirabas contam, tornou-se um monumento, com o acréscimo de uma base de concreto quadrangular. Agora, à primeira vista não lembra mais uma figura antropomorfa. Há relatos de que a pedra se encontra mais baixa do que antes, apresentando mudanças em sua região, principalmente por ali ser área de encantaria. Além da transformação do Rei Sabá em monumento, houve o acréscimo de quatro imagens: Iemanjá, Cabocla Mariana, Toia Jarina e Zé Raimundo. A pedra do Rei Sabá fica sobre formações rochosas e calcárias, contendo rico acervo fóssil do período Cenozóico marinho.

As transformações da região são justificadas pela encantaria, mas também pelo movimento natural da maré. Quando alta, a água do mar cobre grande parte dos monumentos e imagens, embora nunca cubra a pedra totalmente. Há relatos e desconfianças, apesar de não ter escutado acusações certeiras, de que algumas destruições que aconteceram no complexo do Rei Sabá tenham sido causadas por mão humana.
2 |Quando submeti esse artigo para avaliação, ainda estava em Pirabas. Fiquei na cidade entre 11 de janeiro e a primeira quinzena de julho, fazendo pequenas visitas a Belém para frequentar o terreiro de Pai Pingo de Oxumaré, pirabense atuante no festejo do Rei Sabá. Ainda em 2020, antes do contexto da pandemia da covid-19, realizei outras visitas e continuei a pesquisa de campo, podendo acompanhar mais um festejo para Rei Sabá. Entretanto, a maior parte desse escrito está baseada, como disse, na experiência de campo de 2018, apenas complementada com a do ano seguinte. 
O encantado tem duas características marcantes. Primeiro, Rei Sabá não tem uma forma fixa, como me disse Mãe Rita de Oxóssi do Templo de Umbanda Oxóssi e Mamãe Oxum. Além disso, é uma entidade muito antiga, um vodunsi velho, segundo Pai Zé Pajé, pai de santo do Templo de Umbanda Ogum Beira Mar e Zé Pelintra. Sua festa é celebrada no dia 20 de janeiro, essa é, igualmente, a data de nascimento do antigo rei de Portugal, que desapareceu, morreu ou encantou-se na batalha de AlcacérQuibir, em 1578 (Ferretti, 2013; Leacock \& Leacock, 1975). Em São João de Pirabas, além das denominações já elencadas, Rei Sebastião é também chamado de pai velho, nego velho, cavaleiro do céu e guerreiro militar.

São Sebastião, soldado romano canonizado por sua fidelidade aos princípios cristãos, da mesma forma é celebrado no dia 20. Portanto, o 20 de janeiro se apresenta em São João de Pirabas enquanto uma multiplicidade de celebrações a diversos tipos de personagens, tais como Rei Sebastião (Rei Sabá), São Sebastião e Oxóssi. Há discordância, por parte tanto da igreja católica, quanto dos afrorreligiosos, a respeito de determinadas associações feitas entre essas personagens, contudo, não é objetivo deste artigo fazer distinções fenomenológicas e históricas dessas personagens, que possuem trajetórias e histórias distintas. Para Pai Sival, não deve haver a confusão entre Rei Sabá e São Sebastião, cada um tendo o seu próprio espaço na Pena e Maracá, Umbanda amazônica e Mina.

As pessoas em Pirabas com quem conversei não parecem perceber Rei Sebastião como o encoberto que retornará para estabelecer a ordem na terra (Ferretti, 2013). Pai Sival conta que em versões anteriores do festejo para Rei Sabá, a prefeitura trouxe (como uma solicitação dos terreiros) para falar de sebastianismo e outras questões, a antropóloga Anaíza Vergolino, e o finado e importante pai de santo da mina paraense, Pai Tayandô. Essa interlocução, de interesse dos afrorreligiosos, mostra a multiplicidade de Rei Sabá na região. Além de todas essas maneiras de Rei Sabá se manifestar, podemos dizer que "o retorno do rei acontece a cada festa pública, sempre que um filho-de-santo recebe esta entidade" (Luca, 2010: 112).

Veremos adiante que não é fácil receber o Rei Sabá, assim como o seu culto e as oferendas dedicadas a ele são tentativas de aproximar o encantado de volta à região. Rei Sabá dissera para Maria Pajé, que foi umas das mais importantes lideranças de Pirabas, que se ausentaria, durante um tempo, da Praia do Castelo, mudando-se temporariamente para a Ilha dos Lençóis no Maranhão. Maria Pajé marcou tanto Pirabas e a região que foi construído um Centro Cultural e Desportivo com o seu nome. Dona Caçula, mãe de sangue de Mãe Rita, conta: Maria Pajé trabalhava com Pena e Maracá e só se utilizava da linha virada (trabalhos da esquerda e quimbanda) para proteção. Foi essa mãe de santo que orientou o prefeito Bosco Moisés na implementação das imagens no complexo do Rei Sabá. E essa história do distanciamento de Rei Sabá foi contada por Dona Caçula em maiores detalhes, passando por frequentadores do centro de umbanda branca que mencionei. 
Contudo, desde alguns anos atrás, Rei Sabá tornou a se aproximar, a partir dos cultos prestados a ele e da intensificação de seu festejo. Dona Caçula, mãe de Mãe Rita de Oxóssi, por ter vivenciado a época da Maria Pajé, sendo apadrinhada pela afamada mãe de santo e pajé, ressalta que Rei Sabá, irritado com o desrespeito em seus festejos, com pessoas que iriam ao evento apenas para beber, ou fazer outras atividades que não respeitá-lo e cultuá-lo, resolvera partir. Nesse momento a sua pedra abaixou. Contudo, Bosco Moisés, então prefeito na época, por perceber na festividade de Rei Sabá como o evento que mais movimentava a cidade, trazendo várias pessoas de fora do município, consultou os búzios com a Maria Pajé, indagando como poderia fazer com que Rei Sabá se agradasse novamente e retornasse. Assim, foi autorizado para ele fazer as modificações na região, acrescentando a base no Rei Sabá e a construção das imagens de Zé Raimundo, lemanjá, Cabocla Mariana e Tóia Jarina. Esse emaranhado de agenciamentos que engaja poder público e encantaria, será tratado e desenvolvido ao longo desse texto.

\section{A CIDADE}

Por conta desses esforços em conjunto, Pirabas, nas vésperas da festividade, é atravessada por diversas formas de religiosidade, sobretudo a fro umbandista (maneira como estão se identificando alguns terreiros da região para o poder local e sociedades exógenas) e da pajelança amazônica. Por essas religiões terem uma fundamentação ontológica na encantaria, às vezes as denominarei de religiões da encantaria, o que engloba a umbanda amazônica, a pena e maracá (pajelança) e a mina. Aqui, os encantados caboclos convivem com voduns e orixás (em Prandi [2004] temos vasto material sobre os encantados, mestres e caboclos). Nem todos os caboclos são indígenas, alguns são turcos, outros de várias outras nações europeias, conforme podemos conferir nos trabalhos de Taíssa Tavernard de Luca (2010). Essa característica do caboclo no tambor de mina, objeto de tese de Mundicarmo Ferretti (2000), ainda tem muito a nos dizer e não deve ser lida de maneira apressada.

Trarei a procissão para São Sebastião mobilizadas por afro umbandistas da cidade como um lócus de expressão e marca das religiões de encantaria. Nessa perspectiva, essas religiões constroem a própria cidade. Para tal, há todo um esforço por parte das lideranças religiosas, em negociação com os poderes públicos locais, para que suas festividades ocorram e sejam devidamente amparadas e reconhecidas. Com isso, percorrem pela cidade discursos que descrevem as festividades e as religiões aqui tratadas enquanto expressões da história e da cultura local, capazes de transcender esses espaços-tempos produzidos.

São João de Pirabas é uma cidade situada no nordeste paraense. Seu litoral é constituído pelas águas do oceano atlântico e do rio Pirabas. Possui aproximadamente 22 mil habitantes e uma área de 701, $896 \mathrm{~km}^{2}$ segundo dados do IBCE. Umas das 
principais atividades econômicas da cidade é a pesca, tendo como a empresa mais importante da cidade, atualmente em declínio, o empreendimento de pesca Princomar. Do ponto de vista da história colonial, os primeiros povoados que se têm notícia na região são vilas que foram formadas no final do século XIX:

\begin{abstract}
A respeito da versão "oficial" da ocupação do território onde se localiza o município de São João de Pirabas, a maioria dos escritos sobre a origem, dentre algumas diferenças, apontam para o que seriam os primeiros anos de ocupação daquele local, essa ocupação teria ocorrido entre 1895 e 1901. Naquele primeiro ano, em 06 de julho de 1895, segundo Theodoro Braga e Palma Muniz o local ganhou a condição de povoado, pertencente ao município de Salinópolis. Em 1901 o então povoado de São João passou para a denominação de vila através da Lei estadual n 79768. Essa informação está contida em todas as referências à essa origem, mas é claro que se está falando em ocupação dos que vieram de fora, contudo há indícios de ocupação por populações nativas, como da explicação lendária dada anteriormente, sobre sociedades indígenas que evidentemente teriam habitado o local não só em Pirabas mas nas ilhas ao seu entorno e no imenso território da região amazônica (Santos e Silva, 2007: 43).
\end{abstract}

Após estar associada a outros municípios do salgado paraense, tais como Salinópolis e Primavera, em 1988 São João de Pirabas se emancipa. Atualmente, a pavimentação da cidade se restringe a algumas vias principais que ligam os equipamentos centrais, como as escolas públicas, o mercado, a orla, a Princomar, o cemitério, as praças, uma delas a praça matriz, de frente para a Paróquia de São João Batista, e a praça onde estão a Assembleia de Deus e a Igreja Universal, um posto da polícia e alguns serviços alimentícios. Essa é a praça mais movimentada da cidade, que fornecia serviço de internet gratuito, o Navega Pará, financiado pelo governo do estado. Uma rápida caminhada, para além desses equipamentos, nos leva a vias sem pavimentação, como, por exemplo, onde estão o centro de umbanda branca, a casa da benzedeira, e o Templo de Umbanda Oxóssi e Mamãe Oxum, este já mais afastado do centro da cidade, ficando em um sítio, atrás das casas construídas para o Conjunto Raimundo Barroso, que também nomeia o bairro e para muitos de seus moradores não faz mais parte da cidade.

Até agora, o único templo afrorreligioso que visitei ao qual se tem acesso por uma pavimentação é a rua do Templo de Ogum Beira Mar e Zé Pelintra, liderado por Pai Zé Pajé. De qualquer forma os aspectos percebidos como mais rurais são importantes para esses religiosos e as entidades conviventes. Constroem um território repleto de igarapés, olhos d'água e seres vegetais, muitos deles sendo plantas de força ${ }^{3}$, revestindo a territorialidade desses lugares com o fundamento e axé necessários para a manutenção da religião.

Pensar como as religiões de encantaria marcam a cidade de São João de Pirabas, assim como produzem efeitos distintos em sua constituição, é uma tentativa de ampliar
3| Essas plantas intensificam a atuação de pajés, mães e pais de santo, assim como dos encantados. 
os estudos afro-brasileiros, que se consolidaram em grandes aglomerados urbanos (Carneiro, 1977; Leacock e Leacock, 1975; Rabelo, 2014; Conçalves da Silva, 1993). Já no Pará, os estudos desenvolvidos em cidades em zonas rurais e com menor densidade populacional tiveram seu foco na pajelança dita cabocla e amazônica (Cavalcante, 2008; Maués, 1995; Villacorta, 2000; 2011). A minha pesquisa tem se desenvolvido entre pais e mães de santo, mas que também têm fundamentação na pena e maracá, maneira como é denominada a pajelança que acontece dentro dos terreiros (Quintas, 2007). Em São João de Pirabas, caruanas, palavra usada pelos antigos para denominar os encantados, assim como a encantaria e o fundo se fazem presente junto a orixás, caboclos, voduns e exuns. ${ }^{4}$

A respeito de São João de Pirabas e a encantaria de Rei Sabá, existem estudos anteriores (Rego, 1983; Santos e Silva, 2007; Vergolino-Henry, 2008), embora todos eles sejam pontuais, com exceção de Gerson Santos e Silva (2007), que desenvolveu sua dissertação sobre a encantaria de Rei Sebastião na perspectiva da história cultural. Por ainda não existir uma pesquisa que se dedique de forma etnográfica aos terreiros da região e a encantaria do Rei Sabá, resolvi construir a minha tese de doutoramento sobre o assunto.

\section{A PROCISSÃO, A MISSA E O TOQUE DE TAMBOR}

Conversando com algumas pessoas que participam das religiões afro umbandistas da cidade, assim como professores e secretários da prefeitura, rapidamente se percebe que a celebração ao Rei Sabá é considerada uma marca da cultura popular e da história de São João de Pirabas. Relatarei, daqui em diante, os rituais que acompanhei em 2018, trazendo de vez em quando a experiência de 2019 para complementar o quadro.

Alto-falantes, montados em veículos, anunciavam uma procissão. Esta saiu da casa de Mãe Rita de Oxóssi e teve percurso até a Paróquia de São João Batista, onde o padre celebrou uma missa, derrocando em um toque de tambor e cânticos, feitos pelos afrorreligiosos de Pirabas e pelos que vieram de outras cidades. O evento aconteceu no centro cultural e desportivo Maria Pajé, outra obra construída na gestão da prefeitura de Bosco Moisés. Além dos alto-falantes, a cidade escutou a chamada para o luau, que não pude acompanhar, organizado pelo ex-prefeito, ligado à colônia de pescadores de Pirabas. Esses anúncios sonoros possuíam trechos de cânticos afro-brasileiros e enfatizavam as palavras-chave: cultura, história e religiosidade de São João de Pirabas.

No dia 19 de janeiro houve a procissão que saiu da casa de Mãe Rita de Oxóssi ${ }^{5}$. Não alcancei a casa de Mãe Rita a tempo, então esperei a procissão passar na porta da igreja. Enquanto isso, Ana Marcia, uma senhora conhecedora de muitas coisas sobre a cidade, me apresentou a Paulinho Pinheiro, autor de um blog a respeito de São João de Pirabas, em que são abordados assuntos históricos, culturais, políticos e policiais da localidade. Paulo contou-me os nomes de pais, mães de santo e pajés antigos da cidade,
4 | No terreiro de Mãe Rita, a mãe, as filhas e os filhos de santo chamam de exun a entidade que organiza o povo da rua, os trabalhos materiais e, às vezes, a denominada linha virada, entre os mais antigos, e a linha da esquerda, entre os mais jovens. Os Leacock (1975) encontraram o mesmo termo em Belém. Importante ressaltar que no terreiro de Mãe Rita há o uso simultâneo e sinonímico de exun e exu.

5 | Mãe Rita mora na região central da cidade, foi de lá que saiu a procissão, pois o seu congá fica no Conjunto Raimundo Barroso, quase na entrada da cidade, bastante distante para uma caminhada. Não pude acompanhar a saída da procissão de sua casa no ano de 2018 , contudo, no ano de 2019 pude assistir uma gira em sua casa, assim como a saída da procissão, guiada e narrada, via locução em um carro de som, por Pai Sival. 
enquanto reforçava as palavras que já tinha ouvido de outras pessoas, que atualmente a cidade está deixando de lado as potencialidades culturais e turísticas, principalmente no que concerne aos modos populares de festejar e cultuar os santos e Rei Sabá.

Aproximadamente 30 pessoas, vestidas de branco e vermelho, revestidas com as roupas comumente usadas em situações rituais na mina e umbanda paraenses, chegaram ao primeiro destino da procissão. As pessoas seguiam um carro, que levava em sua retaguarda uma berlinda toda enfeitada com fitas coloridas, na qual estava apoiado o santo em uma barquinha: o andor de São Sebastião". 6

Após a chegada dos afrorreligiosos, todos entraram na paróquia, que possui como padroeiro São João Batista. A missa durou das 19 até mais ou menos 21 horas. Seu público, em grande parte, era formado por afrorreligiosos, sendo a minoria que não estava em vestes de terreiro. Percebia-se que essa era uma missa extraordinária, tendo a missa cotidiana acontecido naquele mesmo dia, mas no período vespertino. 0 padre enfatizou "a presença de afro-brasileiros", destacando ser importante o convívio respeitoso entre as religiões e diversas outras denominações, ressaltando que o mais importante de tudo era "buscar a Deus". Narrou a história de São Sebastião, enfatizando seu registro histórico, portanto, o verdadeiro em sua visão, e seu reconhecimento oficial enquanto santo da Igreja Católica Apostólica Romana.

Em certo momento da missa, aproveitou para dizer a seu público que São Sebastião e Rei Sabá não são as mesmas personagens, reforçando que São Sebastião existiu, estando no registro documental e oficial, enquanto Rei Sabá, segundo o padre, faz parte das lendas populares, tendo relatos de pessoas mais velhas, os antigos, de que ele teria realizado milagres. "Pode ter acontecido, pode não ter acontecido", argumentou o padre, "Quem sou eu para dizer alguma coisa?".

Contudo, ficou ressaltada a distinção que o padre faz entre uma personagem reconhecida pela igreja, e outra, reverenciada pelas religiões de encantaria. $\mathrm{Na}$ bibliografia sobre o tema, há sugestões de que exista uma confusão entre Rei Sabá e São Sebastião. Em Pirabas, encontrei mais uma apreciação e devoção a uma multiplicidade que perpassa Rei Sabá - Rei Sebastião, São Sebastião e Oxóssi, do que qualquer confusão. Pelo contrário, as pessoas com quem conversei sabiam muito bem o que estavam fazendo.

Aqui, cortaremos nossa narrativa por um instante. Rei Sabá, que pode ser corruptela de Sebastião, apresenta-se em sua materialidade na própria pedra, embora tenha sua morada na encantaria. Seu lar estende-se pelo litoral paraense e maranhense, sendo forte a referência às praias dos Lençóis no Maranhão. Quando perguntei para Pai Zé Pajé a respeito de Rei Sabá e a sua diferença para São Sebastião, ele delineou: Rei Sebastião é um rei do fundo, um encantado do fundo, ele é um vodunsi? velho, já São Sebastião é um santo guerreiro. Sobre a antiguidade do encantado, importante notar essa ênfase em várias narrativas. Cabocla Mariana, na croa de Mãe Rita, apelida Rei Sabá de pai velho. Essa percepção do encantado é encontrada em outros terreiros. Sariza
6|O andor desse ano foram dados por alguém ligado à prefeitura. Já o santo, Mãe Rita não soube me informar quem havia doado. Em 2019, o andor-barquinha de São Sebastião foi encomendada por um xará do santo, um senhor habitante de Boa Vista, região pesqueira do município de Quatipuru, igualmente no salgado paraense. O santo foi Mãe Rita quem providenciou.

7| Vodunsi: denominação para quem é filho de vodum no tambor de mina. 
Venâncio (2019) em sua etnografia a respeito dos encantados na Umbanda no norte do Tocantins, dialogou com uma mãe de santo que além de receber Rei Sebastião, denominando-o de "velho", festeja o encantado a cada dois anos, sempre no 20 de janeiro, juntamente com São Sebastião, lembrado anualmente.

Para Pai Sival, a distinção levantada pelo padre já teria sido ressaltada por ele mesmo: "a nossa parte na igreja era como cristãos católicos, a missa celebrada no dia 19 de janeiro é para São Sebastião, o santo da igreja católica", continuando "porque somos católicos e temos essa devoção". Ele explica que a missa não pode ser realizada no dia de São Sebastião, justamente por conta do festejo ao Rei Sabá.

Rei Sabá, da maneira como surgiu na pesquisa, é uma força a atravessar toda a região. Materializado na sua pedra, nos pontos de força e encantaria: o oceano, rios, cacimbas, olhos d'águas e muito mais, se faz presente nos dizeres e nas práticas da cidade, tanto entre afro umbandistas, quanto em leigos. Mãe Rita de Oxóssi, eventualmente, recebe Rei Sabá, e apesar de nossa convivência, não pude presenciar essa manifestação. Complementando o quadro, Mãe Rita diz que Rei Sabá pode se transformar em muitas formas animais e humanas.

Embora Roger Bastide tenha sofrido críticas de estudiosos das religiões de matriz africana no Pará, principalmente por ele ter elaborado suas análises praticamente em cima da pesquisa de outros, a participação, descrito por Bastide sobretudo em Algumas considerações em torno de uma "lavagem de contas" (1973), deve dizer alguma coisa sobre o que acontece nessa multiplicidade de personagens vivenciados em São João de Pirabas. Afinal, ali, Bastide decreta que "todos os orixás são múltiplos" (Bastide, 1973: 363), apesar de ainda estar para serem realizadas pesquisas em profundidade que dirão se essa afirmação vale para os encantados, se para todos ou apenas algum deles. Além disso, devemos nos lembrar do aspecto transformacional do próprio Rei Sabá: se não tem uma forma fixa, ele pode se associar a e se transformar em muitos seres. Em 2019 a imagem do santo em seu andor-barquinha, a mesma utilizada na procissão, foi levada até a pedra do Rei Sabá, ali, se encontraram o Santo e o Rei.

A respeito das relações entre catolicismo e as religiões de encantaria, podemos dizer que muitos dos que se dedicam a esta se consideram cristãos. Não é incomum que pajés se declarem como seguidores dos princípios católicos, e até mesmo como evangélicos (Vaz Filho, 2016; Maués, 1995; Silva, 2014). No censo religioso realizado na cidade em 2010, 15.731 pessoas se declararam de religião católica apostólica romana, 3.907 de religião evangélica. Apenas 20 pessoas se declararam espíritas. Quanto a quantidade de terreiros, fui auxiliado por Pai Sival e Mãe Rita nessa contagem, e em atividade, temos cinco terreiros, mas acredito que o número seja muito maior, pois aqui não estou contando as casas menores, os quintais de cura, pajés, rezadores e curadores que atuam sozinhos, tais como Dona Oneide.

As declarações sugerem que há uma convivência entre essas religiões, nas quais as pessoas transitam com certa facilidade. Afinal, as manifestações afro e da pajelança 
estão no calendário oficial da cidade, apresentadas como um compósito de religião e cultura. Apesar das religiões afro e a pajelança não aparecem no censo, elas são visualizadas e ouvidas pelas ruas da cidade, principalmente nas vésperas da festa do Rei Sabá.

Retornemos para o final da missa. Ao longo desta, o padre destacou a importância da festividade do Rei Sabá por atrair pessoas de fora e fazer parte do calendário cultural da cidade. Ao final da missa, Pai Sival foi convidado a falar. Ele agradeceu ao padre a receptividade, anunciando os nomes dos pais e mães de santo que vieram de Belém e Ananindeua, região metropolitana da capital, para a festividade.

Após a missa, os afrorreligiosos se dirigiram para o centro desportivo e cultural Maria Pajé, onde

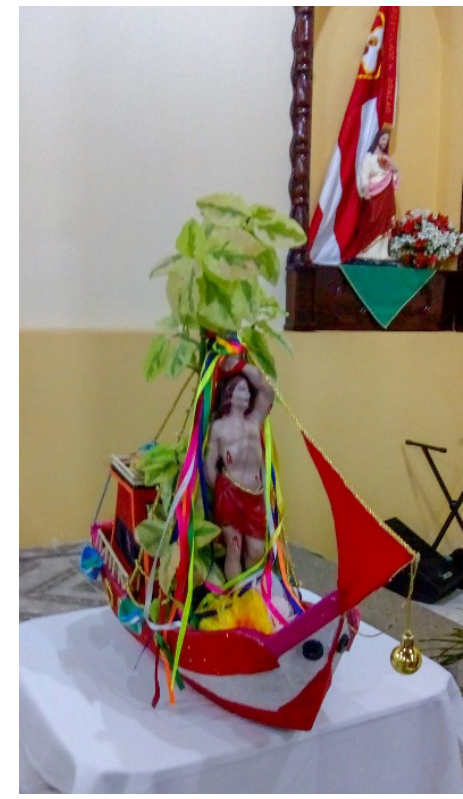

Figura 1 São Sebastião trazido pela procissão. Foto do autor (2018). aconteceu uma gira, que foi até tarde da noite, na praça que fica defronte ao centro. Foram realizados toques de tambores e cânticos para os encantados, Rei Sebastião, São Sebastião, Oxóssi, e muitas outras entidades espirituais, a depender da manifestação dos encantados na cabeça de seus filhos e filhas que estavam na gira. Junto ao som dos atabaques, havia um pequeno equipamento de som para ampliação da voz de quem puxasse os pontos cantados. Um cântico que se repete nesse momento, além de muitos outros referentes a essa festividade, é o seguinte:

\author{
Rei, Rei, Rei \\ Rei Sebastião \\ Quem desencantar Lençol \\ Põe abaixo o Maranhão
}

O local onde aconteceu a gira, o centro cultural Maria Pajé, fica na orla da cidade, sendo uma construção ampla e aberta. Ao seu redor, estão quiosques de concreto, uma quadra de basquete e uma quadra de futsal. Possui em um de seus lados, o contíguo à rua, pinturas evocando a pedra do Rei Sabá, as praias ao redor da cidade e os monumentos às entidades que foram construídos entorno do Rei Sabá, formando um complexo integrado. As artes são assinadas por "Adriano Artes". Ele é o mesmo artista que assina algumas outras pinturas em paredes que encontrei na cidade, como parte dos desenhos das paredes do terreiro de Pai Zé Pajé.

Maria Pajé, como já mencionei, deu o nome ao centro cultural e foi uma importante pajé de pena e maracá de Pirabas. Auxiliou o prefeito, na época de sua gestão (2000-2008), na escolha das entidades que teriam suas imagens construídas e transformadas em monumento na ilha da Fortaleza. Ela quem dera o fundamento 
para que a obra fosse feita de acordo com a religião. No centro cultural há uma placa explicitando um pouco de sua história:

\begin{abstract}
Flaviana Serrão da Silva, "Maria Pajé". Como era conhecida por nossa sociedade. Nasceu em Igarapé Miri, em 24 de janeiro de 1929. Adotou São João de Pirabas como sua pátria. Quando ainda era uma vila de Primavera. Destacou-se como amante da cultura popular. Tendo fundado grupo de marujada de São Benedito. Além de se voltar para outras atividades folclóricas, como o carimbó. Seu trabalho incentivou a juventude a também se interessar pela cultura popular regional, proporcionando a divulgação de São João de Pirabas através das artes. "Maria Pajé" faleceu em 20 de setembro de 2003, em São João de Pirabas, onde permaneceu pelos últimos 42 anos de vida. Emprestar seu nome a este espaço cultural e desportivo é a homenagem post mortem que a sociedade lhe presta, em reconhecimento ao seu amor pelo município".
\end{abstract}

Destaco que apesar da alcunha de pajé, o que está em relevo na trajetória da personagem é a sua ação para a cultura local e atividades denominadas de "folclóricas". Para os propósitos desse artigo, não me aprofundarei sobre as festividades que aconteceram no dia 20 de janeiro, mas reforço que era comum ouvir de representantes da prefeitura e outros agentes públicos que a celebração fazia parte da cultura, história e incentivo ao turismo da cidade. O prefeito, junto com sua família, participou da celebração e a prefeitura construiu uma barraca/rancho na praia da Fortaleza, para alimentação de parte dos afrorreligiosos e seus funcionários, assim como um bote com salvavidas percorreu a praia. A celebração foi divulgada pelo site da prefeitura, incluindo na programação as atividades que ocorreram desde a procissão até a festividade. No dia 20 de janeiro, além de afrorreligiosos, havia diversos banhistas e outras pessoas que vieram para acompanhar a celebração e/ou aproveitaram para apreciar as festas de

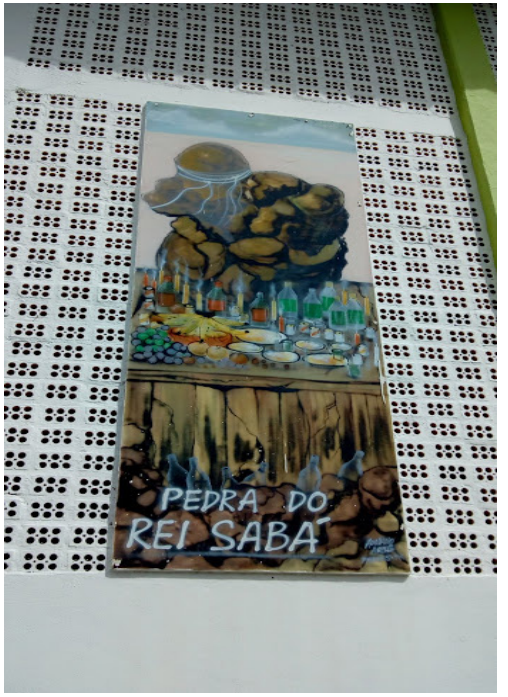

Figura 2. Lateral do centro Maria Pajé. Foto do autor (2018) carimbó e de aparelhagem. A TV Liberal, filiada à TV Globo no Pará, esteve na festividade, registrando-a para elaboração de uma reportagem televisiva ${ }^{8}$.

\title{
MARCAS AFRO UMBANDISTAS NA CIDADE
}

Há diversos discursos: sonoros, visuais, sentidos e materializados pelas vias de Pirabas, e ao se atravessar para as ilhas, eles estendem-se, singrando as regiões insulares com discursos a respeito da festividade enquanto cultura e religião. Para os poderes 
locais, a igreja e setores profissionais, o destaque pende para a festividade enquanto cultura, sendo a religião vivenciada mais pelos afrorreligiosos. Tendo em mente os alto-falantes, a divulgação da prefeitura, de blogues e outros agentes midiáticos relacionados a festividade do Rei Sabá, há um ato de tornar pública a existência de afrorreligiosos em São João de Pirabas, assim como na Crande Belém e outras regiões, d'onde vem a maioria dos outros afrorreligiosos. Com suas vestes, tambores e cânticos, desde o dia anterior até o dia 20 de janeiro, e quando atravessam para a ilha com suas vestimentas rituais, tambores, oferendas e obrigações para Rei Sabá, constroem uma paisagem afro-brasileira encantada.

Esse ato é político não somente pela relação que se estabelece entre a prefeitura e os afrorreligiosos. É político no sentido da cosmopolítica. Afinal, além do relacionamento com os humanos, a festividade é uma relação que se estabelece com um encantado: a partir dessa conexão, é solicitada a permissão para se adentrar em seu território, fazendo-se pedidos para que o ano seja farto e próspero. Até um pescador que pega uma garrafa de cachaça que foi ofertada ao Rei Sabá, dizendo que próximo ano trará uma para ele, está em uma relação política com a encantaria. Para o propósito dessa reflexão, foco na política em sentido mais restrito, dialogando com aquilo que Paula Montero disse sobre o tornar público:

\footnotetext{
Um ato ou objeto torna-se público não apenas porque está localizado em um local público, mas porque sua presença naquele local coloca em movimento, para um público, um conjunto de dinâmicas argumentativas e críticas que redimensionam a sua importância política.

Tomando como foco a observação dos processos de produção de publicidade, talvez caiba, no entanto, compreender quais as redes de publicidade que as ações coletivas religiosas fazem emergir e as linguagens que as fazem funcionar no sentido de gerenciar as relações entre as pessoas e os domínios sociais mais institucionalizados (Montero, 2016: 145).
}

Nos vários campos de possibilidades apresentados aqui, é difícil, talvez impossível, apontar que tipos de públicos estão em voga: quem assiste a um jornal sobre a celebração ao Rei Sabá, passando pelas suas vinculações católicas, evangélicas e as diversas nações e terreiros que participam da celebração. Sem contar os pajés, benzedeiras, pais e mães de santo no geral, que celebram Rei Sabá, São Sebastião e Oxóssi no dia 20 de janeiro, sem atravessar para a ilha da Fortaleza, realizando assim o culto em seus próprios espaços religiosos. Nenhum desses públicos, se assim quiséssemos chamá-los, é uniforme, e tampouco poderia consistir em um público fechado. Percebemos uma intricada rede muito mais ampla e repleta de agenciamentos outros, desde a pedra do Rei Sabá, que é um monumento, uma pedra e uma entidade encantada ao mesmo tempo, até as pessoas que se esforçam para que a atividade ainda aconteça todo ano. Temos uma multiplicidade de ações. Mas, obviamente, quem mais consome essas informações publicizadas são os próprios afrorreligiosos. Antes e depois da festividade, 
podemos vê-los comentar sobre o que aconteceu, compartilhando fotos e vídeos pelas redes sociais digitais, principalmente Facebook e WhatsApp. Antes da festividade, Pai Sival faz ou pede para alguém, diversos convites de divulgação, para serem compartilhados nessas redes. Como das figuras 3 e 4.

De qualquer forma, o que quero destacar do trecho de Montero é que aquilo que é posto em público mobiliza um complexo de argumentações e críticas que redimensionam atos políticos. As imagens que foram construídas ao redor de Rei Sabá: Iemanjá, Jarina, Mariana e Zé Raimundo, estavam, em sua maioria, quebradas e desgastadas pela ação do tempo e, talvez, humana. Jarina não está mais em sua base de concreto, e sim, apoiada nela, apenas com seu tronco intacto, mas ainda assim desgastado. Mariana ainda está lá, mas com um braço quebrado. Zé Raimundo, apenas seus pés ficaram na base, sendo possível avistar logo adiante a imagem com o tronco apoiado nas pedras, decapitada. Muitos afrorreligiosos comentavam que o estado em que estão as imagens era vergonhoso, e que isso era responsabilidade da gestão pública. Outros comentavam que afrorreligiosos tinham a responsabilidade de preservar aquelas imagens. Ainda, as duas pessoas já mencionadas que não participam da festividade, uma mãe de santo de umbanda branca e a benzedeira/pajé Dona Oneide, encontram em suas motivações para não visitarem a praia no dia 20, o estado em que estão
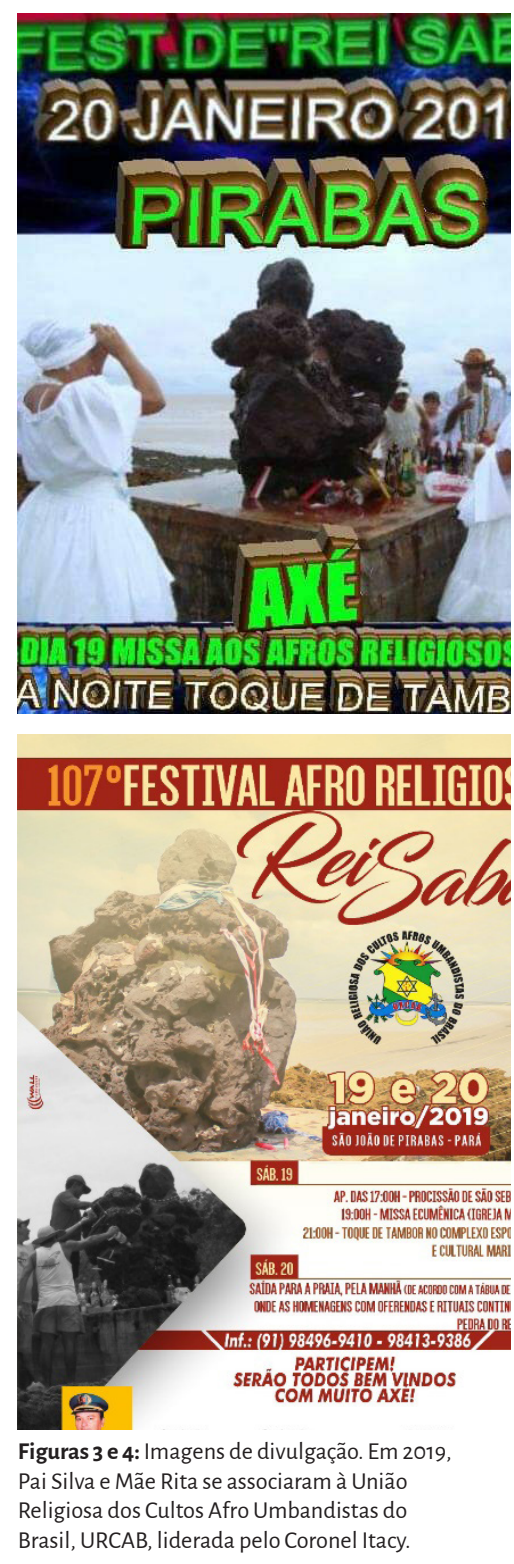
as imagens. A mãe de santo me contou que as entidades certamente estão tristes por conta da degradação das imagens, e que elas não moram mais ali, refugiando-se do outro lado da praia. Ouvi algumas narrativas situada em alguma década passada: por conta do desgaste do local e da decepção dos encantados para com seus devotos, a encantaria de Rei Sabá havia se mudado, em definitivo, para a praia dos Lençóis, no Maranhão.

A mãe de santo de umbanda branca, ainda justificando o motivo de desgostar de participar da festividade, comentou que não apreciava a forma como eram feitas as celebrações, por conta das pessoas consumirem álcool e oferecerem bastante bebida para Rei Sabá - é comum o ato de derramar bebidas alcóolicas na pedra. Ao falar do consumo de álcool pelas entidades e o próprio "cavalo" delas, a mãe de santo conta que 
esse ato vem mais da "nossa cultura", pela "cultura" da "umbanda popular", que criou a imagem de que as entidades bebem. Ela diz que não acha que esse comportamento esteja errado, mas o fundamento do seu terreiro é outro, não inserindo bebidas em seus rituais. Ora, assim, temos mais um significado para a palavra cultura, embora não possa dizer que ela circule no mesmo público que discorre sobre a festividade de Rei Sabá enquanto cultura. Contudo, pode-se dizer que há diversos discursos em jogo, onde cultura, história, religião se entrelaçam e são mobilizados para compor a própria cidade. É nesse aspecto que a proposta de Montero (2016) interessa aqui: pois de antemão, não estamos falando nem de religião na esfera pública, nem de religiões públicas: "a própria atividade coletiva de colocar em cena certos confrontos constroem determinados atores como 'religiosos' e a religião como 'pública'" (Montero, 2016: 144).

É interessante notar que o discurso que folcloriza as religiões afro e a pajelança é compartilhado tanto pela igreja católica, quanto pelo estado, aqui, no nível etnográfico que estamos tratando, a Paróquia de São João Batista e a prefeitura. Nesse aspecto, podemos trazer como um exemplo disjuntivo a pesquisa de Matthew Engelke (2013), se concordarmos que o ato de folclorizar as religiões de matriz africana passa por um certo nível de culturalização das mesmas. Engelke (2013), ao descrever as percepções de um grupo bíblico britânico que, dentre muitas de suas atividades, tinha o propósito de divulgar a Bíblia a partir de diversos modos de publicidade, mostra que uma das estratégias adotadas pelo grupo foi a distribuição de diversos tipos de charadas bíblicas em outdoors, espalhados por Manchester, assim como em descansos de copos em bares. O grupo bíblico se propôs a tal empreitada por considerar que a oposição da Igreja é a própria Cultura. O processo de secularização, segundo o grupo, distanciou a Igreja (religião) do mundo. Assim, a proposta de difundir essas imagens bíblicas, que bebem e se circunscrevem em uma estética da "cultura", pretendia aproximar Igreja e Cultura, pois o grupo não aceita a concepção liberal de religião, no sentido em que ela deveria estar restrita ao âmbito privado (Engelke, 2013). No caso da igreja em Pirabas, a associação entre religião e cultura perpassa a relação que as religiões de matriz africana e a pajelança têm com a encantaria. Aqui, a igreja católica se pensa como a religião, e não precisa se preocupar se estiver apartada das práticas mais mundanas. Além disso, a igreja classifica as religiões de matriz africana e as pajelanças enquanto cultura. Nesse sentido, elas até podem ser reconhecidas como um caminho para Deus, sendo formas quase legítimas" de se chegar até Ele, embora para a igreja dificilmente essas "culturas" sejam equivalentes ao campo religioso católico.

Para a igreja, São Sebastião faz parte de um culto legítimo, pois foi uma personagem histórica, e comprovadamente merece a elevação à categoria de santo. Rei Sabá estaria no registro da cultura-lenda - folclore, pois é cultuado por pessoas de classes populares-afinal, uns dos principais devotos de Rei Sabá são os pescadores, que constantemente avistam-no e percorrem o seu território, assim como afro-brasileiros, rezadeiras, rezadores e pajés. Para a prefeitura, Rei Sabá, seu culto e as religiões da 
encantaria fazem parte da cultura porque conformam uma tradição que dura há dezenas de anos ou mesmo século. Mobiliza a população da cidade e atrai públicos de fora. Portanto, faz parte da cultura local e proporciona turismo para uma região que é famosa por suas praias e balneários, mas que nunca de fato engrenou suas atividades turísticas, como a sua vizinha Salinópolis, famosa pelos seus passeios de férias e praias lotadas no verão.

\section{ANTES DO FIM}

Como vimos, Rei Sabá é múltiplo e se transforma em diversos seres. A partir da procissão de São Sebastião, o santo é convidado a participar da festividade do Rei, assim como no dia 20, constituindo modulações dessas participações e correspondências, Rei Sabá se impregna de Oxóssi, pois conforme conta Mãe Rita de Oxóssi, "Rei Sabá é Oxóssi na umbanda". Além do mais, Pai Sival falou mais de uma vez que se oferece frutas para Rei Sabá, que geralmente seriam ofertadas a Oxóssi, para se pedir que o ano seja próspero e farto.

Muito se pede para o Rei, contudo, o que se oferece? Conforme vimos, a festividade para Rei Sabá esteve abandonada por um tempo, então, o próprio encantado resolvera passar uma temporada na Praia do Lençol, se aproximando da Praia do Castelo apenas no período de sua festividade. Mas com a mobilização das pessoas que cultuam os encantados na região, em relações oscilantes com o poder local, finalmente foi possível retornar à festividade da forma como o Rei gosta: com respeito a ele, de maneira bonita e organizada.

As pessoas com quem conversamos em Pirabas mostram que Rei Sabá enquanto entidade encantada, existe e quer existir. Não estou caindo no mesmo erro de padres e leigos, pois lembremos de Bastide (1973) e seu escrito sobre a lavagem de contas. Ali ele diz que a filosofia do candomblé tem uma concepção de pessoa onde existem vários graus de existência, entre o ser e não ser. Essa filosofia se contrasta com a concepção moderna, em grande parte calcada no racionalismo kantiano, no qual só existe o ser e o não ser, não havendo nenhum espaço entre a possibilidade de existir e o nada. Já na lavagem de contas, assim como em outros rituais afro-brasileiros, a pessoa passa a existir um pouco mais, e isto acrescenta obrigações, tabus e prescrições rituais para aquela pessoa, agora, dedicada a e protegida por algum orixá. Se a pessoa existe com maior intensidade, da mesma forma é o orixá, que agora reina naquela cabeça. Não seria da mesma forma a encantaria do Rei Sabá? Aqui não estamos falando de uma lavagem de contas, mas de diversas operações rituais, festividades, oferendas e obrigações, que tornam pública a existência de sua região encantada, tão encantada e bonita que merece ser vista por mais pessoas. Cabocla Mariana, na cabeça de Mãe Rita disse que Rei Sabá deseja ter mais gente vindo para a sua festa, assim ele será mais reconhecido. O reconhecimento aumenta a sua existência. Pai Sival Dias, em 
registro parecido, conta que há alguns anos a festividade estava abandonada pelo poder público. A comunidade afro umbandista, sem apoio, não conseguiu conduzir a festividade da forma que apraziam a eles mesmos e ao próprio encantado. Essa impossibilidade afastou tanto os religiosos quanto o Rei Sabá. Pai Zé Pajé nos ajuda a entender essa situação passada ao informar que ficou vários anos sem ir à Praia do Castelo, pois a festividade havia perdido sua organização e dedicação para a encantaria. ${ }^{9}$ Foi com muita insistência e mobilização que o apoio desejado retornou. A maior existência de Rei Sabá no mundo implica em maiores obrigações para com ele e a sua encantaria.

Dito isto, diante o poder público local, as religiões da encantaria em São João de Pirabas se inscrevem enquanto cultura no espaço público - diria que mais do que um espaço público sem marcadores, estamos diante um espaço público encantado (Carvalho, 1999), assim como são inscritas em uma legibilidade, algumas vezes ao menos, "diferencialista", isto é, mobilizam argumentos que particularizam a presença dessas religiões no espaço público (Giumbelli, 2008). Mas ainda tem mais. Ao adentrarmos nas comunidades de terreiro que participam dessas festividades e culto ao Rei Sabá e toda a sua encantaria, veremos que essas relações sociais estabelecidas com o poder público é expressão da própria religião. Foi aproximando-se do poder local que se conseguiu que finalmente as imagens quebradas e desgastadas de lemanjá, Mariana, Jarina e Zé Raimundo fossem trocadas em 2019. Com essas ações e outras, as pessoas que vivem essas religiões nutrem a vida de seu próprio encantado e mostram para o mundo a beleza que é o seu reino e a sua morada. Nessa esteira, as festas e festejos são acontecimentos imprescindíveis (Pereira, 2017). Para o mundo da encantaria e os encantados, como a própria Cabocla Mariana nos ensina, é muito importante o gosto pelas coisas e festas bonitas.

Hermes de Sousa Veras é doutorando em Antropologia Social pela Universidade Federal do Rio Grande do Sul e mestre em Antropologia pelo PPCA da Universidade Federal do Pará. É membro dos seguintes grupos de pesquisa: Núcleo de Estudos da Religião (NER/UFRCS), LEBARA - Epistemologia e Religião (UNIFESSPA), Grupo de Estudos Culturais na Amazônia (CECA/UFPA) e Religião, arte, materialidade, espaço público: grupo de antropologia (MARES/UFRGS). Autor de $O$ sacerdote e o aprendiz: antropologia de um terreiro amazônico (2021).

CONTRIBUIÇÃO DE AUTORIA: Não se aplica

FINANCIAMENTO: Este artigo é parte das reflexões provenientes de uma investigação de doutorado que contou com financiamento CAPES.
9| Essa conversa com Pai Sival aconteceu no dia 18 de janeiro de 2019, quando as imagens novas foram transferidas e instaladas na Praia do Castelo. O diálogo ocorreu na única sombra disponível, enquanto estávamos sobre os platôs d'onde estão Rei Sabá e as outras imagens. A conversa com Pai Zé Pajé aconteceu no dia 10 de fevereiro do mesmo ano, em sua casa-terreiro. 


\section{REFERÊNCIAS BIBLIOGRÁFICAS}

BASTIDE, Roger. 1973. "Algumas considerações em torno de uma 'lavagem de contas'. In: BASTIDE, Roger. Estudos AfroBrasileiros. São Paulo, Pioneira. pp. 363-374.

CARNEIRO, Edson. 1977. Candomblés da Bahia. 5ed. Rio de Janeiro,

Civilização Brasileira; Brasília, INL.

CARVALHO, José Jorge de. 1999. Um espaço público encantado. Pluralidade religiosa e modernidade no Brasil. Série Antropologia 249, UNB.

CAVALCANTE, Patricia Carvalho. 2008. De "nascença" ou de "simpatia": iniciação, hierarquia e atribuições dos mestres na pajelança marajoara. Belém, dissertação de mestrado, Universidade Federal do Pará.

ENCELKE, Matthew. 2013. God's Agents: Biblical Publicity in Contemporary England. Berkeley, University of California Press.

FERRETTI, Mundicarmo. 2000.

Desceu na guma: o caboclo no tambor de mina em um terreiro de São Luís: a Casa Fanti-Ashanti. São Luís, EDUFMA.

FERRETTI, Sergio. 2013. Encantaria maranhense de Dom Sebastião. Revista Lusófona de Estudos Culturais, v. 1, n. 1: 262-285.

GIUMBELLI, Emerson. 2008. "A presença do religioso no espaço público: modalidades no Brasil". Religião e Sociedade, v. 28, n. 2: 80-101.

GONÇALVES DA SILVA, Vagner. 1993. "O terreiro e a cidade nas etnografias afro-brasileiras". Revista de Antropologia, v. 36: 33-79.
LEACOCK, Seth; LEACOCK, Ruth. 1975. Spirits of the Deep: A study of na AfroBrazilian Cult. New York, Anchor Books.

LUCA, Taíssa Tavernard de. 2010. "Tem branco na guma": a nobreza europeia montou corte na encantaria mineira. Belém, tese de doutorado, Universidade Federal do Pará.

MAUÉS, Raymundo Heraldo. 1995. Padres, pajés, santos e festas: catolicismo popular e controle eclesiástico. Um estudo antropológico numa área do interior da Amazônia. Belém, CEJUP.

MONTERO, Paula. 2016. “Religiões públicas' ou religiões na esfera pública? Para uma crítica ao conceito de campo religioso de Pierre Bourdieu. Religião \& Sociedade, v. 36, n. 1: 128-150.

PEREIRA, Anderson Lucas da Costa. 2017. A Cabocla Mariana e a sua corte ajuremada: modos de pensar e fazer festa em um terriero de Umbanda em Santarém, Pará. Rio de Janeiro, dissertação de mestrado, Universidade Federal do Rio de Janeiro.

PRANDI, Reginaldo. 2004. Encantaria brasileira: o livro dos mestres, caboclose encantados. Rio de Janeiro: Pallas.

QUINTAS, Gianno Gonçalves. 2007. Entre maracas, curimbas e tambores: pajelanças nas religiões afro-brasileiras. Belém, dissertação de mestrado, Universidade Federal do Pará.

RABELO, Miriam. 2014. Enredos, feituras e modos de cuidado: dimensões da vida e da convivência no candomblé. Salvador, EFUBA.

RECO, José de Moraes. 1983. Litolatria: culto das pedras no Estado do Pará. Belém, Edição do Autor.

SANTOS E SILVA, Gerson. 2007. Encantados da "Fortaleza" insular: D. Sebastião, Natureza 
artigo | Hermes de Sousa Veras | O santo e o encantado: a procissão afro umbandista para São Sebastião em São ]oão de Pirabas

em uma história cultural na Amazônia.

Belém, dissertação de mestrado,

Universidade Federal do Pará.

SILVA E SILVA, Jerônimo da. 2014. Cartografia de afetos na encantaria: narrativas de mestres da Amazônia Bragantina. Belém, tese de doutorado, Universidade Federal do Pará.

VAZ FILHO, Florêncio Almeida.

2016. Pajés, benzedores, puxadorese parteiras. Santarém, UFOPA.

VENANCIO, Sariza Oliveira Caetano. 2019. Encantados na Umbanda no norte do Tocantins. Campinas, tese de doutorado, Universidade Estadual de Campinas.
VERGOLINO-HENRY, Anaíza. 2008. “Um encontro na encantaria: notas sobre a inauguração do 'Monumental Místico Rei Sabá"'. In: MAUÉS, Raymundo Heraldo; VILLACORTA, Gisela Macambira (org.). Pajelanças e Religiões Africanas na Amazônia. Belém, EDUFPA.

VILLACORTA, Gisela Macambira. 2000. As mulheres do pássaro da noite: Pajelança e feitiçaria na região do salgado (nordeste do Pará). Belém, dissertação de mestrado, Universidade Federal do Pará.

VILLACORTA, Gisela Macambira. 2011. "Rosa Azul": Uma xamã na metrópole da Amazônia. Belém, tese de doutorado, Universidade Federal do Pará.

Recebido em 25 de junho de 2019. Aceito em 9 de dezembro de 2020. 